\section{CAFETERIA DIET INCREASES LIQUID INTAKE AND SERUM CREATININE LEVELS IN RATS}

\author{
Roberta Ströher ${ }^{1,2,3}$, Isabel Cristina Macedo ${ }^{1,4}$, \\ Carla de Oliveira ${ }^{1,3,5}$, Vanessa Leal Scarabelot ${ }^{1,2,3}$, Tizye Lima Rizzo', \\ Jeferson Ferraz Goularte ${ }^{1,6}$, Wolnei Caumo ${ }^{5}$, Adriane Belló Klein ${ }^{6}$, \\ Gilberto Luiz Sanvitto ${ }^{6}$, Iraci LS Torres ${ }^{1,2,3,5,6}$
}

\begin{abstract}
Introduction: Important changes in human dietary pattern occurred in recent decades. Increased intake of processed foods leads to obesity, which is related with the development of chronic diseases such as type 2 diabetes mellitus, hypertension, as well as cardiovascular and chronic kidney diseases. The prevalence of hypertension has also dramatically increased in recent years, and high sodium intake contributes to this scenario. In healthy individuals, kidneys are the primary end-organs that regulate sodium homeostasis. This study aims to evaluate renal function parameters and systolic blood pressure measurements in an animal model of obesity.
\end{abstract}

Methods: Sixty-day-old male Wistar rats $(n=30)$ were divided into two groups: standard (SD) and cafeteria diet (CD). Cafeteria diet was altered daily and was composed by crackers, wafers, sausages, chips, condensed milk, and soda. All animals had free access to water and chow and the experiment was carried out for 6 weeks. Weight gain, sodium and liquid intake control, systolic blood pressure measurements, and renal function parameters were evaluated.

Results: Animals exposed to cafeteria diet had an increase of $18 \%$ in weight compared to the control group. Sodium intake was increased by cafeteria diet and time $\left(\mathrm{F}_{(1,28)}=773.666, \mathrm{P}=0.001\right.$ and $\mathrm{F}_{(5,28)}=2.859, \mathrm{P}=0.02$, respectively $)$ and by the interaction of both factors $\left(F_{(6,28)}=2.859, P=0.02\right)$. On liquid intake occurred only effect of cafeteria diet and time $\left(F_{(1,28)}=147.04, P=0.001\right.$ and $F_{(5,28)}=3.996, P=0.003$, respectively). Cafeteria diet exposure also induced an increase on creatinine serum levels $(P=0.002)$, however this effect was not observed on creatinine urine levels $(P>0.05)$ nor on systolic pressure measurements (Students' t test, $P>0.05)$.

Conclusions: Obesity induced by cafeteria diet exposure increases liquid intake and alters creatinine serum levels, an important renal function marker. Considering the high consumption of hypercaloric food currently in the world, further studies are required to elucidate the modifications on renal function triggered by this diet over time.

Keywords: Hypertension; kidney; renal function; obesity; hypercaloric diet

Overweight and obesity are defined as abnormal or excessive fat accumulation that may impair health. In 2014, more than 1.9 billion adults, 18 years and older, were overweight. Among these, over 600 million were obese $^{1}$. The major cause of obesity and overweight is an energy imbalance between calories consumed and calories expended, including the increased intake of energy-dense and nutrient-poor foods which are high in fat and calories. Obesity has long been acknowledged as a significant contributing factor in the development of various chronic diseases such as cardiovascular disease, type 2 diabetes mellitus, stroke, and hypertension, among others ${ }^{2}$. In rats, a palatable diet was adapted from a diet known as cafeteria diet or Western diet $^{3}$, which represents an animal model of obesity. This type of diet includes crackers, wafers, sausages, chips, condensed milk, and soda ${ }^{4}$.
Clin Biomed Res. 2017;37(4):323-329

1 Laboratory of Pharmacology of Pain and Neuromodulation - PreClinical Investigations, Department of Pharmacology, Institute of Basic Health Sciences, Universidade Federal do Rio Grande do Sul (UFRGS). Porto Alegre, RS, Brazil.

2 Graduate Program in Biological Sciences - Pharmacology and Therapeutics, Universidade Federal do Rio Grande do Sul (UFRGS). Porto Alegre, RS, Brazil.

3 Graduate Program in Medical Sciences, Universidade Federal do Rio Grande do Sul (UFRGS). Porto Alegre, RS, Brazil.

4 Universidade Federal do Pampa (UNIPAMPA). São Gabriel, RS, Brazil.

5 Animal Experimentation Unit and Graduate Studies and Research Group, Hospital de Clínicas de Porto Alegre, Universidade Federal do Rio Grande do Sul (UFRGS). Porto Alegre, RS, Brazil.

6 Graduate Program in Biological Sciences - Physiology, Universidade Federal do Rio Grande do Sul (UFRGS). Porto Alegre, RS, Brazil.

Corresponding author: Iraci LS Torres iltorres@hcpa.edu.br Department of Pharmacology, Institute of Basic Health Sciences (ICBS), Universidade Federal do Rio Grande do Sul (UFRGS)

Rua Sarmento Leite, 500.

90050-170, Porto Alegre, RS, Brazil. 
Moreover, hypertension is a major worldwide risk factor for cardiovascular diseases (CVDs) such as heart attack, heart failure, stroke, and peripheral vascular disease. The prevalence of hypertension has dramatically increased in recent years ${ }^{5}$. Furthermore, it is important to note that the combination of obesity and hypertension is related to high morbidity and mortality because it leads to cardiovascular and kidney disease ${ }^{6}$. It has been demonstrated that potential mechanisms linking obesity to hypertension include dietary factors, metabolic, endothelial and vascular dysfunctions, as well as neuroendocrine imbalances, sodium retention, glomerular hyperfiltration, and proteinuria ${ }^{6}$. In addition, high dietary sodium intake is associated with elevated blood pressure, a major risk factor for CVDs ${ }^{7-9}$.

Due to its importance, the control of sodium balance is tightly regulated by several neurohormonal axes in order to maintain the constancy of the internal environment ${ }^{10}$. The major hormones that are involved in sodium and water balance are the antidiuretic hormone (ADH), the aldosterone and the atrial natriuretic hormone (ANH). The first one acts on the kidney promoting water reabsorption, while aldosterone promotes sodium reabsorption and ANH stimulates sodium excretion ${ }^{11}$. In healthy individuals, kidneys are the primary end-organs that regulate sodium homeostasis ${ }^{12}$. High dietary salt intake presents a major challenge for the kidneys to excrete the large amounts of salt administered ${ }^{13}$.

Considering that obesity induced by cafeteria diet ingestion contains high sodium levels and may increase liquid intake, this study aims to evaluate renal function parameters and systolic blood pressure measurements in animals submitted to this model of obesity.

\section{METHODS}

\section{Animals}

A total of 30 male Wistar rats (60-day old; weighing $200-250 \mathrm{~g}$ at the beginning of the treatment; supplied by the Centre for Reproduction and Animal Experimentation (CREAL) of the Institute of Basic Health Sciences (ICBS), Universidade Federal do Rio Grande do Sul (UFRGS)), randomized by body weight and housed in groups of 5 rats per polypropylene cage $(49 \times 34 \times 16 \mathrm{~cm})$. All animals were kept on a standard 12-hour light/dark cycle (lights on at 7.00 a.m. and lights off at 7.00 p.m.), in a temperature-controlled environment $\left(22 \pm 2^{\circ} \mathrm{C}\right)$, and had access to water and chow ad libitum (standard diet or cafeteria diet). All experiments and procedures were approved by the Institutional Animal Care and Use Committee (GPPG-HCPA protocol N 09231) and were compliant with Brazilian guidelines involving use of animals in research (Law $N^{\circ}$ 11.794). Vigorous attempts were made to minimize animal suffering and decrease external sources of pain and discomfort, as well as to use only the number of animals that was essential to produce reliable scientific data.

\section{Experimental Design}

Rats were habituated to the maintenance room for 1 week before the beginning of the experiment and they were divided into 2 groups according to the type of diet provided: standard diet (SD), which received standard chow, and cafeteria diet (CD), which received hypercaloric diet. The animals were weighed weekly, and the food and the liquid intake were recorded daily. The experiment was performed over 6 weeks.

\section{Obesity Model}

Standard rat diet (Nuvilab CR-1, NUVITAL ${ }^{\circledR}$, Curitiba, PR, Brazil) was composed of $55.0 \%$ carbohydrates, $22.0 \%$ protein, $4.5 \%$ lipids, and $18.5 \%$ other constituents (fiber and vitamins); totaling $2.93 \mathrm{kcal} / \mathrm{g}$ (information provided by the manufacturer). The cafeteria diet consisted of about $60.0 \%$ carbohydrates, $20.0 \%$ lipids, $15.0 \%$ protein, and $5.0 \%$ other constituents (sodium, calcium, vitamins, preservatives and minerals); totaling $4.18 \mathrm{kcal} / \mathrm{g}$ (including soda $-0.42 \mathrm{kcal} / \mathrm{mL}$ ). The constituents of each diet are described in Table 1. Calories calculations were based on information provided by the manufacturer on the package's label. The palatable high-calorie diet (cafeteria diet) was chosen because it mimics modern patterns of human food consumption and it has been used successfully in experimental studies to induce obesity in lean animals ${ }^{3}$. This diet was adapted from a diet known as the cafeteria diet or Western diet, previously described by Estadella et al. The cafeteria diet was altered daily; and was composed of crackers, wafers, sausages, chips, condensed milk, and soda. Both the standard chow and the experimental diet were replaced daily with fresh food. All animals had free access to standard chow and water, including the ones that received cafeteria diet.

Table 1: Experimental diets composition.

\begin{tabular}{ccc}
\hline & $\begin{array}{c}\text { Standard diet } \\
(\%)\end{array}$ & $\begin{array}{c}\text { Cafeteria diet } \\
\text { (\%) }\end{array}$ \\
\hline Carbohydrates & 55 & 60 \\
Protein & 22 & 20 \\
Lipids & 4.5 & 15 \\
Other & & \\
constituents & 18.5 & 5 \\
(fibers, vitamins) & & \\
\hline
\end{tabular}




\section{Obesity, Sodium and Liquid Intake}

The consumption per cage of standard chow and cafeteria diet were evaluated weighing daily ingredients from both diets (g). Also, animals were weighed weekly to confirm the presence of obesity induced by the model proposed $(\mathrm{g})$. Values from sodium intake were calculated based on information provided by the manufacturer on foods' labels $(\mathrm{mg})$. The liquid intake was measured daily in graduated cylinder discounting the value of the consumed amount offered to the animals $(\mathrm{mL})$.

\section{Systolic Blood Pressure Measurements}

The systolic pressure was measured in a non-invasive method using a photoelectric sensor attached to a signal amplifier (II TC Life Science Inc., Woodland Hills, CA) connected to a computer, which allows to measure the pressure in the caudal artery in rats ${ }^{14}$. Animals were habituated to the equipment for $1 \mathrm{~h} /$ day for 3 days before the test and placed in a heated restrainer at $37 \pm 1^{\circ} \mathrm{C}$ for 10 minutes. Blood pressure reading was given by the detection of the first artery pulsation during gradual cuff deflation. Each measure was obtained by averaging five individual readings from each animal and results were shown as $\mathrm{mmHg}$.

\section{Renal Function Parameters}

Renal function was evaluated by the determination of creatinine in urine and blood samples (serum). Therefore, this metabolite was measured using a Labtest ${ }^{\circledR}$ kit (Creatinina, ANVISA - 10009010034, MG, Brazil) and following its protocol, through a colorimetric and fluorometric method. Urine samples were collected by cystocentesis, puncturing the bladder with a suitable syringe. Serum samples were obtained by trunk blood centrifugation $(5000 \times \mathrm{g} / 5 \mathrm{~min}$, room temperature) after decapitation. All samples were collected at the end of the experiment. Results were showed as $\mathrm{mg} / \mathrm{dL}$.

\section{Statistical Analysis}

Results were expressed as the mean \pm standard error of the mean (S.E.M.). The data analysis and interactions was evaluated using Student's $t$-test or Paired-Samples $T$ test when necessary. Repeated measures were submitted to ANOVA followed by Bonferroni's test (effect of cafeteria diet, effect of time or effect of cafeteria diet $\times$ time) when necessary. Differences were considered statistically significant if $\mathrm{P}<0.05$.

\section{RESULTS}

\section{Obesity, Sodium and Liquid Intake}

Results of repeated measures ANOVA followed by Bonferroni, (effect of time or cafeteria diet) demonstrated that cafeteria diet increased animals' weekly weight $(F(6,28)=2.249, P=0.001)$ from the third week of treatment. This result reflects an increase of $18 \%$ in the weight of the animals exposed to the cafeteria diet compared to the control group. Moreover, animals' weight increased over time, showing interaction between time and cafeteria diet $(F(6,28)=9.967 \quad P=0.004)$. This effect suggests that both factors (time and cafeteria diet) contribute to the increase of the animals' weight (Figure 1: panel A). The results of repeated measures ANOVA followed by Bonferroni test demonstrated an effect of cafeteria diet $(F(1,28)=773.666, P=0.001)$, of time $(F(5,28)=2.859, P=0.02)$ and interactions between time and cafeteria diet $(F(6,28)=2.859, P=0.02)$ with both factors increasing sodium intake (Figure 1: panel $B)$. On liquid intake occurred effect of cafeteria diet $(F(1,28)=147.04, P=0.001)$ and time $(F(5,28)=3.996$, $\mathrm{P}=0.003$ ) (Figure 1: panel $\mathrm{C}$ ). No interaction between time and cafeteria diet was observed $(P>0.05)$.

\section{Renal Function Parameters}

Cafeteria diet exposure induced an increase on creatinine serum levels $(P=0.002)$, however, this effect was not observed on creatinine urine levels $(P>0.05)$ (Figure 2: panels $A$ and $B$ ).

\section{Systolic Blood Pressure Measurements}

There were no differences between groups on systolic pressure measurements (Students' $t$ test, $\mathrm{P}>0.05$ ) (Figure 3).

\section{DISCUSSION}

In this study, we confirmed that rats exposed to cafeteria diet increased the weight over time. In addition, obesity induced by the cafeteria diet increases liquid intake, which can be attributed to the high sodium intake present in this diet. Despite the high consumption of sodium, and consequently of liquids, no differences were observed in the measurement of systolic pressure. Also, obese animals had creatinine serum levels increased, but no difference was found in urine creatinine levels.

In previous studies our group also showed that the same cafeteria diet protocol achieved obesity and changed parameters that lead to hyperphagia, increase of fat mass and weight gain in rats ${ }^{4}$. It shows that this cafeteria diet protocol may be used as an animal obesity model. This diet consists of a simple exchange of carbohydrate-derived with fat-derived calories when compared to low fat or chow control 
Panel A

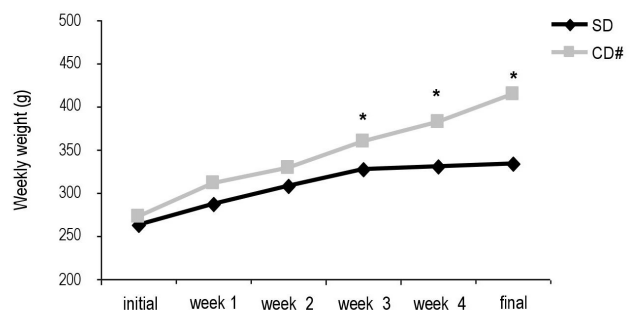

Panel B

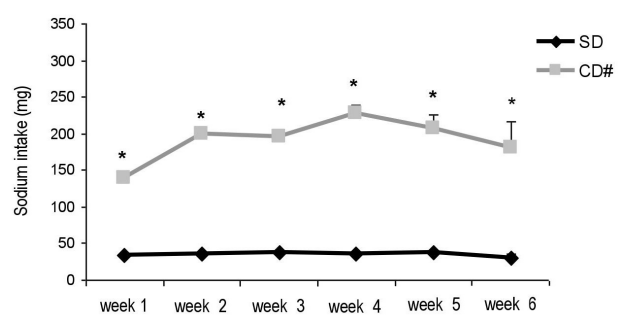

Panel C

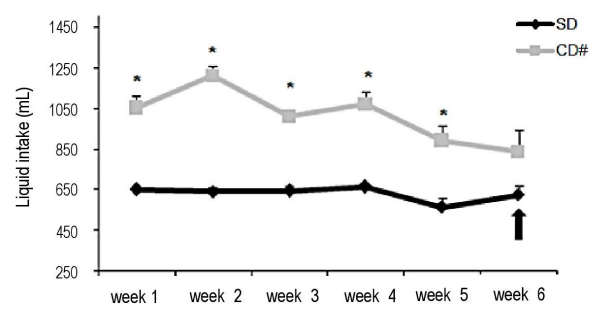

Figure 1: Animals' weight gain (Panel A), sodium (Panel B), and liquid intake (Panel C). SD: standard diet (receiving standard chow) and CD: cafeteria diet (receiving cafeteria diet). $\left(^{*}\right)$ Significant effect of cafeteria diet $(P<0.05)$. (\#) Significant effect of time $(P<0.05)$. Data expressed as mean \pm SEM (repeated measures ANOVA/Bonferroni's test for weekly weight, sodium intake and liquid intake, $\mathrm{n}=15$ animals/group).

diets. This model accurately reflects the variety of highly palatable and energy dense foods that are prevalent in Western society and associated with the current obesity pandemic. Animals were allowed to have free access to standard chow and water while concurrently offered highly palatable, energy dense and unhealthy human foods ad libitum ${ }^{15}$. Several studies agree that this dietary pattern has contributed with overweight and obesity incidence around the world and provide poor eating habits. Moreover, this palatable diet due to its pleasurable experience leads to satisfaction and makes it prone to abuse ${ }^{16,17}$. Besides food ingestion, many genetically modified obesity models have been adopted in the literature, such as ob/ob mice, $d b / d b$ mice, Zucker fa/fa obese rats, Agouti yellow mice, and melanocortin 4 receptor knockout mice ${ }^{15,18-20}$.
Panel A

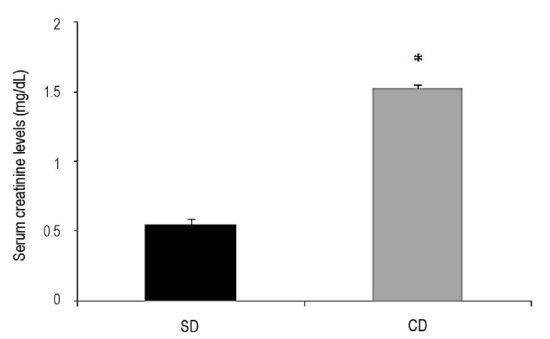

Panel B

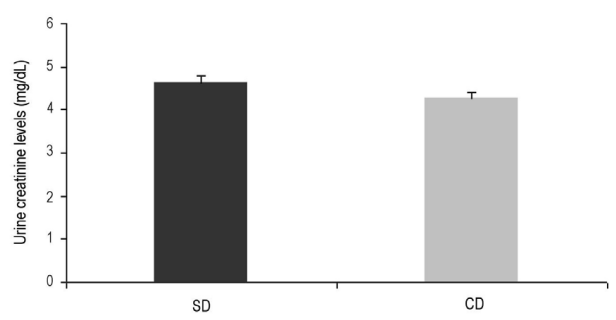

Figure 2: Animals' creatinine serum (Panel A) and urine (Panel B) levels. SD: standard diet (receiving standard chow) and CD: cafeteria diet (receiving cafeteria diet). $\left(^{*}\right)$ Significant effect of cafeteria diet. Data expressed as mean \pm SEM (Student's $T$ test, $n=7$ animals/group).

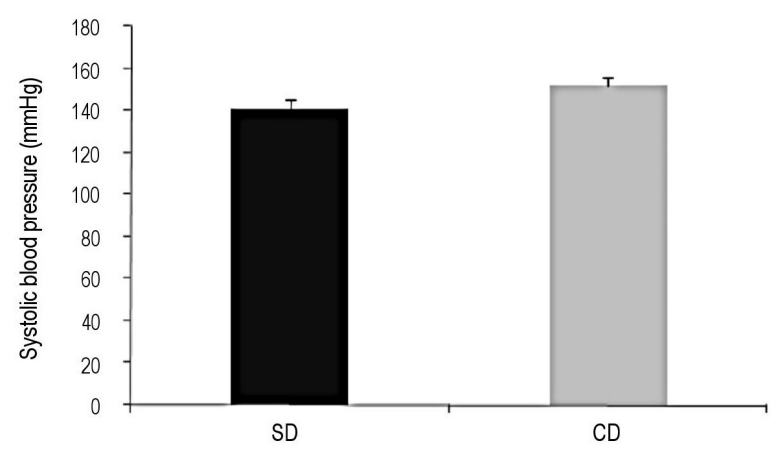

Figure 3: Animals' systolic blood pressure measurements. SD: standard diet (receiving standard chow) and CD: cafeteria diet (receiving cafeteria diet). Data expressed as mean \pm SEM (Student's $T$ test, $n=5$ animals/group, $P>0.05$ ).

The obesity model applied in this study contains high sodium content that exceeds the limits recommended by the guidelines ${ }^{21}$. High sodium intake is associated with the development of cardiovascular diseases including hypertension ${ }^{22,23}$. The association between sodium intake and thirst is well established. Sodium intake increases the plasma sodium, and then thirst is stimulated in order to maintain homeostasis ${ }^{24,25}$. This phenomenon was shown in our study, where animals exposed to the cafeteria diet consumed more sodium and consequently higher liquid intake. 
Obesity is a great risk factor for hypertension and other comorbidities that may contribute to the development of chronic renal damage ${ }^{26,27}$. High sodium intake increases blood pressure, induces glomerular hyperfiltration and affects renal function ${ }^{28}$. Obesity causes vasodilatation and renal glomerular hyperfiltration that act as a compensatory mechanism to maintain the body's homeostasis, in order to keep sodium balance despite the increased tubular reabsorption. This mechanism becomes vicious because these offsets with blood pressure increase can lead to glomerular injury ${ }^{27}$. Although there is a strong relationship between sodium intake and hypertension, animals exposed to cafeteria diet for 6 weeks did not show increase in blood pressure. This was probably due to the small number of sample size selected to evaluate systolic blood pressure measurements $(n=5)$, which we consider one of the main limitations of our study. We speculate that the duration of the treatment was also insufficient to trigger hypertension in these animals, considering that another study showed a robust increase in systolic blood pressure with animals exposed to cafeteria diet for 10 weeks ${ }^{29}$.

The most important function of the kidney is filtration and excretion of nitrogenous compounds from blood ${ }^{30}$. Creatinine is a good parameter for assessing renal function, since its production only depends on the muscle cell metabolism and is almost entirely eliminated by glomerular filtration ${ }^{30-32}$, and by poor tubular secretion ${ }^{33}$, that may be considered insignificant. Therefore, the intensity of creatinine excretion corresponds to the rate of glomerular filtration, so if glomerular filtration decreases, its excretion also decreases transiently, increasing its levels in body fluids and plasma until the creatinine excretion returns to normal ${ }^{34}$. In our study, animals exposed to cafeteria diet had higher serum creatinine levels. Urinary creatinine levels were higher than serum levels in both groups; in spite of this, there was no difference between the groups under study. It is important to emphasize that creatinine presents low tubular reabsorption and is excreted in the urine in large quantity. The apparent normality in its excretion occurs at the expense of elevated serum creatinine concentration, which accumulates in almost the same proportion as the number of nephrons lose their filtration capacity ${ }^{34}$. We emphasize the relevance of this result, since it is known that an increase in the serum creatinine levels is suggestive of incipient and progressive loss of renal function.

On the other hand, protein intake in large quantities can decline renal function with a progressive loss of renal capacity ${ }^{35}$. Although this metabolism and the amount of protein present in serum may be influenced by several factors ${ }^{36}$, our study did not observe difference between groups in the total serum protein levels (data not shown).

As exposed above, this study showed that obesity induced by cafeteria diet exposure can increase liquid intake and alter serum creatinine levels, an important renal function marker. Considering the high consumption of hypercaloric food currently in the world, further studies are required to elucidate the modifications on renal function triggered by this diet over time.

\section{Acknowledgements}

This research was supported by the following Brazilian funding agencies: Conselho Nacional de Desenvolvimento Científico e Tecnológico - CNPq (Dr. Iraci Lucena da Silva Torres, Dr. Wolnei Caumo; Vanessa Leal Scarabelot); Coordenação de Aperfeiçoamento de Pessoal de Nível Superior - CAPES (Isabel Cristina de Macedo, Carla de Oliveira, Roberta Ströher) and Grupo de Pesquisa e Pós-graduação do Hospital de Clínicas de Porto Alegre - GPPG/HCPA (Iraci LS Torres - GRANT 09231) PIBIC HCPA/CNPq.

\section{Conflicts of interest}

The authors declare no conflicts of interest.

\section{REFERENCES}

1. World Health Organization (WHO). Obesity and overweight. 2016. [cited 2016 Mar 10]. Available from: http:// www.who.int/mediacentre/factsheets/ fs311/en/.

2. Adeboye B, Bermano G, Rolland C. Obesity and its health impact in Africa: a systematic review. Cardiovasc J Afr. 2012;23(9):512-21. PMid:23108519. http://dx.doi.org/10.5830/CVJA-2012040.
3. Estadella D, Oyama LM, Dâmaso AR, Ribeiro EB, Oller Do Nascimento $\mathrm{CM}$. Effect of palatable hyperlipidic diet on lipid metabolism of sedentary and exercised rats. Nutrition. 2004;20(2):218-24. PMid:14962690. http://dx.doi.org/10.1016/j. nut.2003.10.008.

4. Macedo IC, Medeiros LF, Oliveira C, Oliveira CM, Rozisky JR, Scarabelot VL, et al. Cafeteria diet-induced obesity plus chronic stress alter serum leptin levels. Peptides. 2012;38(1):18996. PMid:22940203. http://dx.doi. org/10.1016/j.peptides.2012.08.007.

5. Mills KT, Bundy JD, Kelly TN, Reed JE, Kearney PM, Reynolds K, et al. Global disparities of hypertension prevalence and control: a systematic analysis of population-based studies from 90 countries. Circulation. 2016;134(6):441-50. PMid:27502908. http://dx.doi.org/10.1161/ CIRCULATIONAHA.115.018912. 
6. DeMarco VG, Aroor AR, Sowers JR. The pathophysiology of hypertension in patients with obesity. Nat Rev Endocrinol. 2014;10(6):364-76. PMid:24732974. http://dx.doi. org/10.1038/nrendo.2014.44.

7. Mozaffarian D, Fahimi S, Singh GM, Micha R, Khatibzadeh S, Engell $\mathrm{RE}$, et al. Global sodium consumption and death from cardiovascular causes. N Engl J Med. 2014;371(7):62434. PMid:25119608. http://dx.doi. org/10.1056/NEJMoa1304127.

8. Thomas J, Chan L, Wray A, Miller J, Mehta K, Yaxley A, et al. Does the presence of cardiovascular disease risk factors or established disease influence the dietary intake of affected adults and their children residing in the same household? A secondary analysis of the Australian Health Survey (2011-2013). BMC Cardiovasc Disord. 2017;17(1):146. PMid:28583073. http://dx.doi. org/10.1186/s12872-017-0578-2.

9. Hao Z, Li G, Sun Y, Liu Y. Relationship and associated mechanisms between ambulatory blood pressure and clinic blood pressure with prevalent cardiovascular disease in diabetic hypertensive patients. Medicine (Baltimore). 2017;96(16):e6756. PMid:28422891. http://dx.doi. org/10.1097/MD.0000000000006756.

10. Gross CG. Claude Bernard and the constancy of the internal environment. Neuroscientist. 1988;4(5):380-5. http:// dx.doi.org/10.1177/107385849800400 520.

11. Hall JE. Guyton and Hall textbook of medical physiology. 13th ed. São Paulo: Elsevier Editora Ltda; 2016.

12. Mc Causland FR, Waikar SS, Brunelli SM. The relevance of dietary sodium in hemodialysis. Nephrol Dial Transplant. 2013;28(4):797802. PMid:23129821. http://dx.doi. org/10.1093/ndt/gfs452.

13. Ha SK. Dietary salt intake and hypertension. Electrolyte Blood Press. 2014;12(1):7-18. PMid:25061468. http://dx.doi.org/10.5049/ EBP.2014.12.1.7.

14. Safaeian L, Hajhashemi V, Haghjoo Javanmard S, Sanaye Naderi $H$. The Effect of Protocatechuic Acid on Blood Pressure and Oxidative Stress in Glucocorticoid-induced Hypertension in Rat. Iran J Pharm Res. 2016;15(Suppl):83-91. PMid:28228807.
15. Sampey BP, Vanhoose AM, Winfield $\mathrm{HM}$, Freemerman AJ, Muehlbauer MJ, Fueger PT, et al. Cafeteria diet is a robust model of human metabolic syndrome with liver and adipose inflammation: comparison to highfat diet. Obesity (Silver Spring). 2011;19(6):1109-17. PMid:21331068. http://dx.doi.org/10.1038/oby.2011.18.

16. Lenard NR, Zheng $\mathrm{H}$, Berthoud HR. Chronic suppression of mu-opioid receptor signaling in the nucleus accumbens attenuates development of diet-induced obesity in rats. Int J Obes (Lond). 2010;34(6):100110. PMid:20065959. http://dx.doi. org/10.1038/ijo.2009.297.

17. Pinto Júnior DAC, Seraphim PM. Cafeteria diet intake for fourteen weeks can cause obesity and insulin resistance in Wistar rats. Rev Nutr. 2012;25(3):313-9. http://dx.doi.org/10.1590/S141552732012000300001.

18. Drel VR, Mashtalir N, Ilnytska O, Shin J, Li F, Lyzogubov VV, et al. The leptin-deficient (ob/ob) mouse: a new animal model of peripheral neuropathy of type 2 diabetes and obesity. Diabetes. 2006;55(12):333543. PMid:17130477. http://dx.doi. org/10.2337/db06-0885.

19. Lutz TA, Woods SC. Overview of animal models of obesity. Curr Protoc Pharmacol. 2012;(5.61). PMid: 22948848. http://dx.doi. org/10.1002/0471141755.ph0561s58.

20. Li S, Zhai X, Rong P, McCabe MF, Wang $X$, Zhao J, et al. Therapeutic effect of vagus nerve stimulation on depressive-like behavior, hyperglycemia and insulin receptor expression in Zucker fatty rats. PLoS One. 2014;9(11):e112066. PMid:25365428. http://dx.doi. org/10.1371/journal.pone.0112066.

21. World Health Organization (WHO). Guideline: sodium intake for adults and children. Geneva: World Health Organization; 2012.

22. Wright JA, Cavanaugh KL. Dietary sodium in chronic kidney disease: a comprehensive approach. Semin Dial. 2010;23(4):415-21. PMid:20557489. http://dx.doi.org/10.1111/j.1525139X.2010.00752.x.

23. McMahon EJ, Bauer JD, Hawley CM, Isbel NM, Stowasser M, Johnson DW, et al. The effect of lowering salt intake on ambulatory blood pressure to reduce cardiovascular risk in chronic kidney disease (LowSALT CKD study): protocol of a randomized trial. BMC Nephrol. 2012;13(1):137. PMid:23082956. http://dx.doi. org/10.1186/1471-2369-13-137.

24. Grimes CA, Riddell LJ, Campbell $\mathrm{KJ}$, Nowson CA. Dietary salt intake assessed by $24 \mathrm{~h}$ urinary sodium excretion in Australian schoolchildren aged $5-13$ years. Public Health Nutr. 2013;16(10):178995. PMid:22894920. http://dx.doi. org/10.1017/S1368980012003679.

25. Grimes CA, Wright JD, Liu K, Nowson $\mathrm{CA}$, Loria $\mathrm{CM}$. Dietary sodium intake is associated with total fluid and sugarsweetened beverage consumption in US children and adolescents aged 2-18 y: NHANES 2005-2008. Am J Clin Nutr. 2013;98(1):18996. PMid:23676421. http://dx.doi. org/10.3945/ajcn.112.051508.

26. Thethi T, Kamiyama M, Kobori H. The link between the renin-angiotensinaldosterone system and renal injury in obesity and the metabolic syndrome. Curr Hypertens Rep. 2012;14(2):1609. PMid:22302531. http://dx.doi. org/10.1007/s11906-012-0245-z.

27. Hall ME, Carmo JM, Silva AA, Juncos LA, Wang Z, Hall JE. Obesity, hypertension, and chronic kidney disease. Int J Nephrol Renovasc Dis. 2014;7:75-88. PMid:24600241. http:// dx.doi.org/10.2147/IJNRD.S39739.

28. Koo HS, Kim YC, Ahn SY, Oh SW, Kim S, Chin HJ. Analysis of correlation between 24-hour urinary sodium and the degree of blood pressure control in patients with chronic kidney disease and non-chronic kidney disease. J Korean Med Sci. 2014;29(Suppl 2):S117-22. PMid:25317015. http:// dx.doi.org/10.3346/jkms.2014.29. S2.S117.

29. Pons Z, Guerrero L, Margalef $M$, Arola L, Arola-Arnal A, Muguerza B. Effect of low molecular grape seed proanthocyanidins on blood pressure and lipid homeostasis in cafeteria diet-fed rats. J Physiol Biochem. 2014;70(2):629-37. PMid:24610672. http://dx.doi.org/10.1007/s13105-0140329-0.

30. Basile DP, Anderson MD, Sutton TA Pathophysiology of acute kidney injury. Compr Physiol. 2012;2(2):130353. PMid:23798302.

31. Odden MC, Shlipak MG, Tager IB. Serum creatinine and functional limitation in elderly persons. $J$ 
Gerontol A Biol Sci Med Sci. 2009;64(3):370-6. PMid:19181716. http://dx.doi.org/10.1093/gerona/ gln037.

32. Carter CE, Gansevoort RT, Scheven L, Heerspink HJL, Shlipak MG, de Jong PE, et al. Influence of Urine Creatinine on the Relationship between the Albumin-to-Creatinine Ratio and Cardiovascular Events. Clin
J Am Soc Nephrol. 2012;7(4):595603. PMid:22383750. http://dx.doi. org/10.2215/CJN.09300911.

33. Narayanan S, Appleton HD. Creatinine: a review. Clin Chem. 1980;26(8):1119-26. PMid:6156031.

34. Hall JE. Tratado de fisiologia médica. 12th ed. Rio de Janeiro: Elsevier; 2011.
35. Martin WF, Armstrong LE, Rodriguez NR. Dietary protein intake and renal function. Nutr Metab (Lond). 2005;2(25). PMid:16174292. http:// dx.doi.org/10.1186/1743-7075-2-25.

36. Feldman BF, Zinkl JG, Jain NC. Schalm's veterinary hematology. Hoboken (NJ): Wiley-Blackwell; 2000.

Received: July 03, 2017 Accepted: Aug 31, 2017 